\title{
Cross-reactions in cell-mediated immunity to Salmonella causing enteric fever
}

\author{
HEMLATTA TIWARI and R. S. KAMAT \\ Department of Clinical Pathology, Haffkine Institute, Parel, Bombay 400012 , India
}

\begin{abstract}
Summary. Cross-reactivity in a delayed-type hypersensitivity (DH) response was studied in mice immunised with live Salmonella typhi, S. paratyphi A and S. paratyphi B. Extensive cross-reactions outside the serogroup limits were observed. The ability of DH cross-reacting and non-cross-reacting sonicates to generate activated macrophages was studied in mice immunised 3 months earlier with $S$. paratyphi B. Whereas DH cross-reacting $S$. poona sonicate generated activated macrophages the non-crossreacting $S$. typhi sonicate did not. To determine whether infections due to diarrhoeacausing salmonellae generated cross-reactive cell-mediated immune responses against enteric fever-causing organisms, similar reverse experiments were performed in mice immunised with $S$. enteritidis. $S$. paratyphi A sonicate generated both effector responses, i.e., $\mathrm{DH}$ and activated macrophages.
\end{abstract}

\section{Introduction}

It is generally accepted that the most important immune response in enteric fever is cell-mediated immunity (CMI) (Collins, 1974). Whether such an immune status is modified by attacks of mild salmonella enteritis is not known. Theoretically this is possible provided the salmonellae responsible for the two forms of disease are antigenically related. The well established antigenic relationships that comprise the Kauffman-White scheme (Edwards and Ewing, 1972) are based on somatic and flagellar antigens. If these antigens are not involved in CMI the present concept of serogrouping may have no relevance to cross-immunity in infections due to different salmonellae. In tests of CMI cross-reactions beyond the serogroup limits and with non-flagellate strains have been reported (Nair and Kamat, 1982). We report an investigation of the cross reactions in which two different expressions of CMI, delayed hypersensitivity (DH) and protective immunity, were studied in mice infected with enteric strains of salmonella.

\section{Materials and methods}

\section{Bacterial}

Salmonella abortus equi $(\mathrm{O} 4,5,12 ; \mathrm{Hg}, \mathrm{m}, \mathrm{x}) \mathrm{NCTC}$ 5727, S. paratyphi C (O6, 7, Vi; H o, 1, 4, 5) NCTC 9325, S. typhi $(\mathrm{O} 9,12, \mathrm{Vi} ; \mathrm{Hd}) \mathrm{NCTC} 8385, S$. anatum $(\mathrm{O} 2,3,9$;

Received 9 Apr. 1985; accepted 24 Jun. 1985.

Correspondence and requests for offprints should be sent to Dr R.S. Kamat.
$\mathrm{He}, \mathrm{h}, 1,6)$ NCTC 5779, S. aberdeen $(\mathrm{O} 9 ; \mathrm{H} \mathrm{i}, 1,2)$ NCTC 5792 and $S$. poona $(\mathrm{O} 13,22 ; \mathrm{Hz}, 1,6)$ NCTC 5791 were obtained from the National Collection of Type Cultures, Colindale Avenue, London NW9 5HT. An S. enteritidis $(\mathrm{O} 1,9,12 ; \mathrm{Hj}, \mathrm{m})$ strain was isolated from naturally infected mice in the animal colony of the Haffkine Institute. A rough mutant of $S$. enteritidis was obtained after repeated subcultures in vitro. Strains of $S$. typhimurium $(\mathrm{O} 1,2,12 ; \mathrm{H} 9)$ and $S$. paratyphi $\mathrm{B}(\mathrm{O} 1,4,5,12 ; \mathrm{H} \mathrm{b}, 1$, 2) were isolated from patients. They were serotyped at the Central Research Institute, Kasauli, India.

\section{Animals}

Swiss white mice weighing 18-20 g were used throughout. A representative batch of 10 mice from each lot was tested for DH response to the sonicates of strains of Salmonella used for immunising and cross-reactivity studies. If one mouse showed a positive reaction the entire batch was discarded.

\section{Sonicated antigen}

Salmonellae from an overnight culture on nutrient agar were suspended in phosphate buffered saline (PBS), pH 7.2 , killed by $\gamma$ radiation (2.4 Mrad), washed in PBS and disrupted by sonication (Branston Sonic Power Co., USA). The resultant material was centrifuged at $50000 \mathrm{~g}$ for $1 \mathrm{~h}$. Protein content of the supernate was assayed by the method of Lowry et al. (1951), and appropriate adjustments made by dilution or by concentration after vacuum dialysis.

\section{Immunisation}

Two groups of Swiss white mice were immunised as 
follows: (1) with three intraperitoneal (Ip) injections of live $S$. typhi or $S$. paratyphi A or $S$. paratyphi B containing, respectively $c .10^{3}, 10^{4}$ and $10^{5} \mathrm{cfu}$ in $0.5 \mathrm{ml}$ of PBS, given at weekly intervals; (2) with five ip injections of live $S$. enteritidis given at weekly intervals. Because the LD50 of the smooth strain of $S$. enteritidis was $6 \mathrm{cfu}$, the first two injections contained, respectively, c. $10^{5}$ and $10^{7}$ cfu of the rough mutant strain, and the final three contained, respectively, c. $10^{2}, 10^{3}$ and $10^{4} \mathrm{cfu}$ of the smooth strain of $S$. enteritidis.

\section{Delayed hypersensitivity tests}

The mouse foot-pad technique of Gray and Jennings (1955) was used to test for DH. A $0.03-\mathrm{ml}$ volume of bacterial sonicate containing $c$. $50 \mu \mathrm{g}$ of protein was injected into the hind footpad, and measurements of footpad thickness made before, $24 \mathrm{~h}$ and $48 \mathrm{~h}$ after injection. The sonicate of the immunising species was injected into the left hind foot-pad and the test species in the right. Each sonicate was tested in at least five mice that gave a positive DH response to the sonicate of the immunising species. Results were expressed as corrected foot-pad enlargement (CFPE), which is the difference in the footpad enlargements of the test and non-immune control mice. All results were analysed by Student's $t$ test (Freund, 1967).

\section{Generation of activated macrophages}

The ability of the sonicated antigen to generate activated macrophages (AM) in the animals immunised with live salmonellae was tested by the technique of Nair and Kamat (1982), which is a modification of the assay of Blanden et al. (1966). Mice were immunised with one of the test species as described above. After a 3-month rest period to permit decline of $\mathrm{AM}$ generated during immunisation itself, the mice were given an ip injection of the test sonicate containing $100 \mu \mathrm{g}$ of protein. AM was assessed after $36 \mathrm{~h}$ by assay of bactericidal activity of peritoneal exudate cells (PEC) against $S$. enteritidis. Irrespective of the immunogen and the test sonicate employed for stimulation, an identical challenge with $S$. enteritidis was given so that all the bactericidal profiles could be compared. As negative controls, non-immune mice were similarly stimulated with each test sonicate and the bactericidal activity of their PEC assayed.

\section{Microbicidal activity of PEC}

Each mouse was given an ip injection of $c .2 \times 10^{4} \mathrm{cfu}$ of smooth $S$. enteritidis preopsonised with heat-inactivated rabbit antibody, and was killed by cervical dislocation exactly 5 min later. Chilled Hanks's Balanced Salts Solution (HBSS; $2 \mathrm{ml}$ ) containing heat-inactivated rabbit antiserum against heat-killed $S$. enteritidis $2 \% \mathrm{v} / \mathrm{v}$, newborn-calf serum $10 \% \mathrm{v} / \mathrm{v}$ and heparin $20 \mathrm{IU}$, was immediately injected ip into the mouse, the abdomen was massaged and the contents aspirated. PEC from several mice were pooled and washed. The number (cfu) of unphagocytosed bacteria in the washings was assessed. The washed PEC pellet was suspended $\left(c .6 \times 10^{6} \mathrm{cells} / \mathrm{ml}\right)$ in warm HBSS containing newborn-calf serum $12 \% \mathrm{v} / \mathrm{v}$, $1-\mathrm{ml}$ volumes were incubated at $37^{\circ} \mathrm{C}$ for various periods and one portion was chilled immediately. After incubation, $\mathbf{0} \cdot 1 \mathrm{ml}$ of saponin was added to a final concentration of $2.5 \% \mathrm{v} / \mathrm{v}$ to lyse PEC. Lysates were kept on ice until dilution and plating for counting viable bacteria. The percentage of organisms killed at each time point was calculated with reference to the number of cfu injected.

\section{Results}

Delayed hypersensitivity cross-reactions of strains of Salmonella causing enteric fever

Batches of 4-6-week-old Swiss white mice were immunised with $S$. typhi, $S$. paratyphi A and $S$. paratyphi $\mathrm{B}$ and $\mathrm{DH}$ responses were tested after one week. Extensive cross-reactions with other salmonellae, of a pattern quite different from that expected from the groupings of the KauffmanWhite scheme, were observed. There were intergroup cross-reactions. The order of the crossreaction between two species of the same serogroup was not necessarily greater than that observed between two species of different serogroups. The extent and spectrum of cross-reactivity was not the same for the three immunogens (table I).

Generation of activated macrophages by DH crossreacting sonicates in mice immunised with $S$. paratyphi $B$

To determine if $\mathrm{DH}$ cross-reactions correlated with protective $\mathrm{CMI}$, the ability of $\mathrm{DH}$ crossreacting and non-cross-reacting sonicates to generate AM in mice immunised with $S$. paratyphi B was investigated. PEC of mice immunised 3 months earlier but not stimulated with antigen before the assay of their bactericidal activity, phagocytosed and killed a maximum of $6 \%$ of the challenge salmonellae in $35 \mathrm{~min}$. However, after stimulation with a sonicate of $S$. paratyphi B $36 \mathrm{~h}$ before the assay, the bactericidal activity was enhanced and PEC killed c. $50 \%$ of the challenge salmonellae in 5 min. The sonicate of $S$. poona which showed a DH cross-reaction with $S$. paratyphi $B$ also enhanced the bactericidal activity of PEC from mice immunised with of $S$. paratyphi B and $c .31 \%$ of challenge salmonellae were killed in $5 \mathrm{~min}$. In contrast, no enhancement of the bactericidal activity of PEC from mice immunised with $S$. paratyphi B was observed after stimulation with $S$. typhi sonicate which did not show any DH cross-reaction with the 
Table 1. Delayed hypersensitivity response in mice immunised with enteric-fever strains of Salmonella elicited by other salmonellae

\begin{tabular}{|c|c|c|c|c|c|c|c|c|c|c|}
\hline \multirow[b]{2}{*}{ Immunogen } & \multicolumn{10}{|c|}{ Increase in mean $( \pm$ SEM) footpad thickness $(\mathrm{mm})$ at $48 \mathrm{~h}$ elicited by } \\
\hline & $\begin{array}{l}\text { S. para- } \\
\text { typhi A } \\
\text { (A)† }\end{array}$ & $\begin{array}{l}\text { S. para- } \\
\text { typhi B } \\
\text { (B) }\end{array}$ & $\begin{array}{l}\text { S. typhi- } \\
\text { murium } \\
\text { (B) }\end{array}$ & $\begin{array}{l}\text { S. abortus- } \\
\text { equi } \\
\text { (B) }\end{array}$ & $\begin{array}{l}\text { S. para- } \\
\text { typhi C } \\
\text { (C) }\end{array}$ & $\begin{array}{l}\text { S. enteri- } \\
\text { tidis } \\
\text { (D) }\end{array}$ & $\begin{array}{l}\text { S. typhi } \\
\text { (D) }\end{array}$ & $\begin{array}{c}\text { S. anatum } \\
\text { (E) }\end{array}$ & $\begin{array}{l}\text { S. aber- } \\
\text { deen } \\
\text { (F) }\end{array}$ & $\begin{array}{l}\text { S. poona } \\
\text { (G) }\end{array}$ \\
\hline S. typhi & $* 0.11 \pm 0.05$ & $0.06 \pm 0.06$ & $* 0.11 \pm 0.05$ & $* 0.075 \pm 0.02$ & $* 0.18 \pm 0.05$ & $0.09 \pm 0.03$ & $* 0.22 \pm 0.04$ & $0.17 \pm 0.07$ & $* 0.10 \pm 0.03$ & ${ }^{*} 0.18 \pm 0.03$ \\
\hline$S$ paratyphi $A$ & $* 0.19 \pm 0.05$ & $0.02 \pm 0.03$ & $0.09 \pm 0.06$ & $* 0.15 \pm 0.06$ & ${ }^{*} 0.17 \pm 0.04$ & $0.06 \pm 0.06$ & $0.03 \pm 0.04$ & $0.03 \pm 0.06$ & $0.07 \pm 0.05$ & $* 0.16 \pm 0.04$ \\
\hline
\end{tabular}

* Significant at $\mathrm{p}<0.05$

+ Kauffman-White serogroups in parenthesis.

former. PEC of these mice could kill a maximum of $7 \%$ of challenge salmonellae in $5 \mathrm{~min}$. Sonicates tested in non-immune mice showed no enhancement of bactericidal activity of PEC. The bactericidal profiles described above were analysed by Student's $t$ test and the differences observed were statistically significant $(\mathrm{p}<0.05)$ (fig. 1).
Generation of $D H$ and $A M$ by enteric fever-causing salmonellae in mice immunised with $S$. enteritidis

The DH responses of mice immunised with $S$. enteritidis to the sonicates of S. typhi, S. paratyphi A and $S$. paratyphi B are shown in table II. All three sonicates generated a good $\mathrm{DH}$ response.

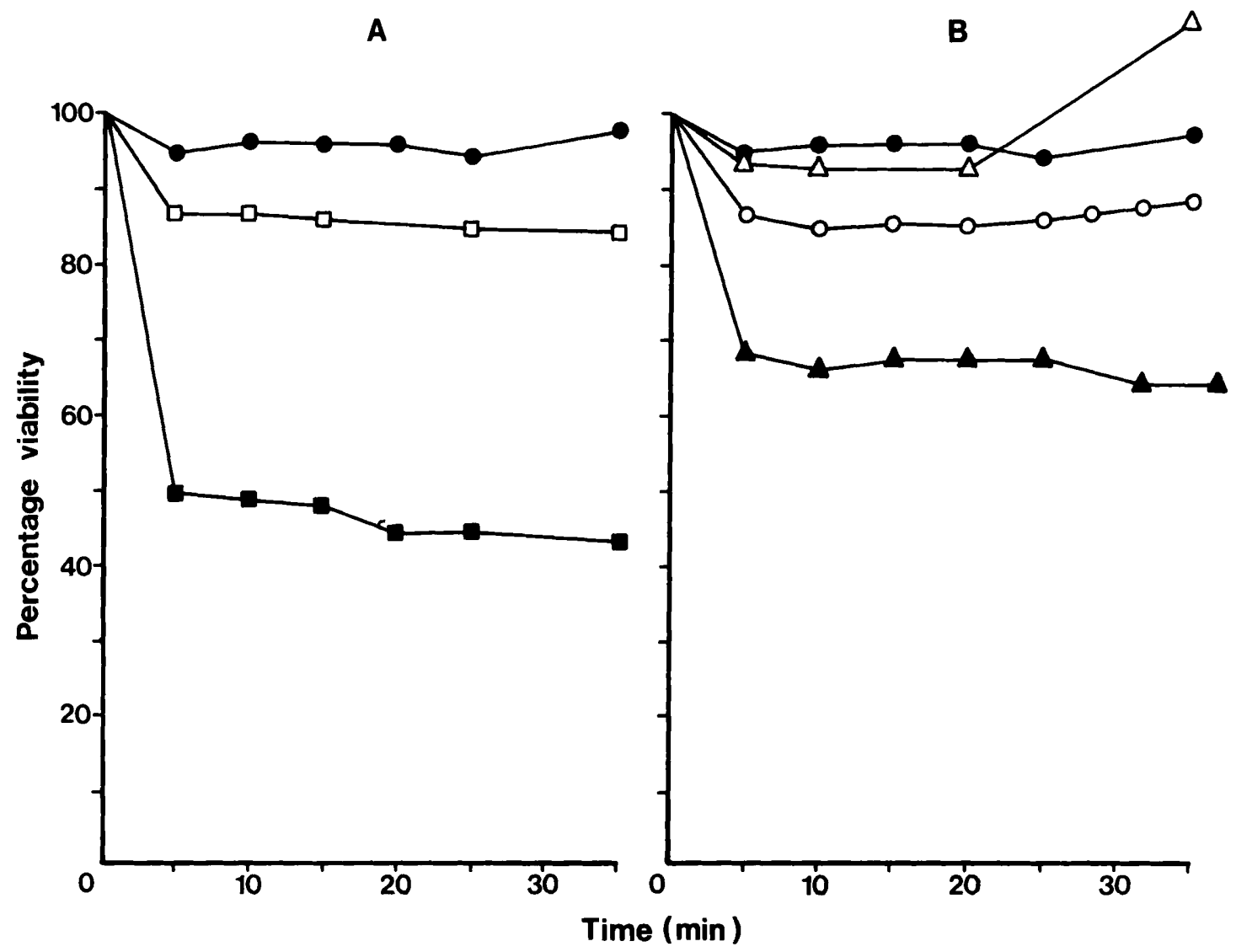

Fig. 1 (A and B). Bactericidal activity of pooled PEC of mice: immunised 3 months before with $S$. paratyphi B but not stimulated

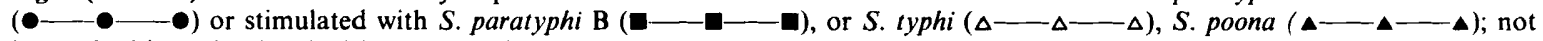
immunised but stimulated with $S$. paratyphi B ( $\square-\square-\square)$, or $S$. poona (O-O- 
The ability of $S$. paratyphi A sonicate to generate AM was also tested 3 months after immunisation. PEC of mice immunised 3 months earlier and not stimulated, with any sonicate killed a maximum of $14 \%$ of challenge salmonellae in $35 \mathrm{~min}$. After stimulation with $S$. enteritidis sonicate, $c .61 \%$ of challenge salmonellae were killed in $5 \mathrm{~min}$. The sonicate of $S$. paratyphi A which showed DH crossreaction with $S$. enteritidis also enhanced the bactericidal activity; c. $49 \%$ of challenge salmonellae were killed in $5 \mathrm{~min}$. None of these sonicates caused enhancement of bactericidal activity of PEC of nonimmune mice. These results were statistically significant $(\mathrm{p}<0.05)$. (fig. 2$)$.

Table II. Delayed-hypersensitivity responses in mice immunised with $S$. enteritidis elicited by enteric-fever salmonellae

\begin{tabular}{l|c}
\hline Sonicate tested & $\begin{array}{c}\text { Increase in mean }( \pm \text { SEM) footpad thickness }(\mathrm{mm}) \\
\text { at } 48 \mathrm{~h}\end{array}$ \\
\hline S. typhi & $* 0.26 \pm 0.05$ \\
S. paratyphi A & $* 0.20 \pm 0.07$ \\
S. paratyphi B & $* 0.24 \pm 0.08$ \\
\hline
\end{tabular}

* Significant at $p<0.05$.

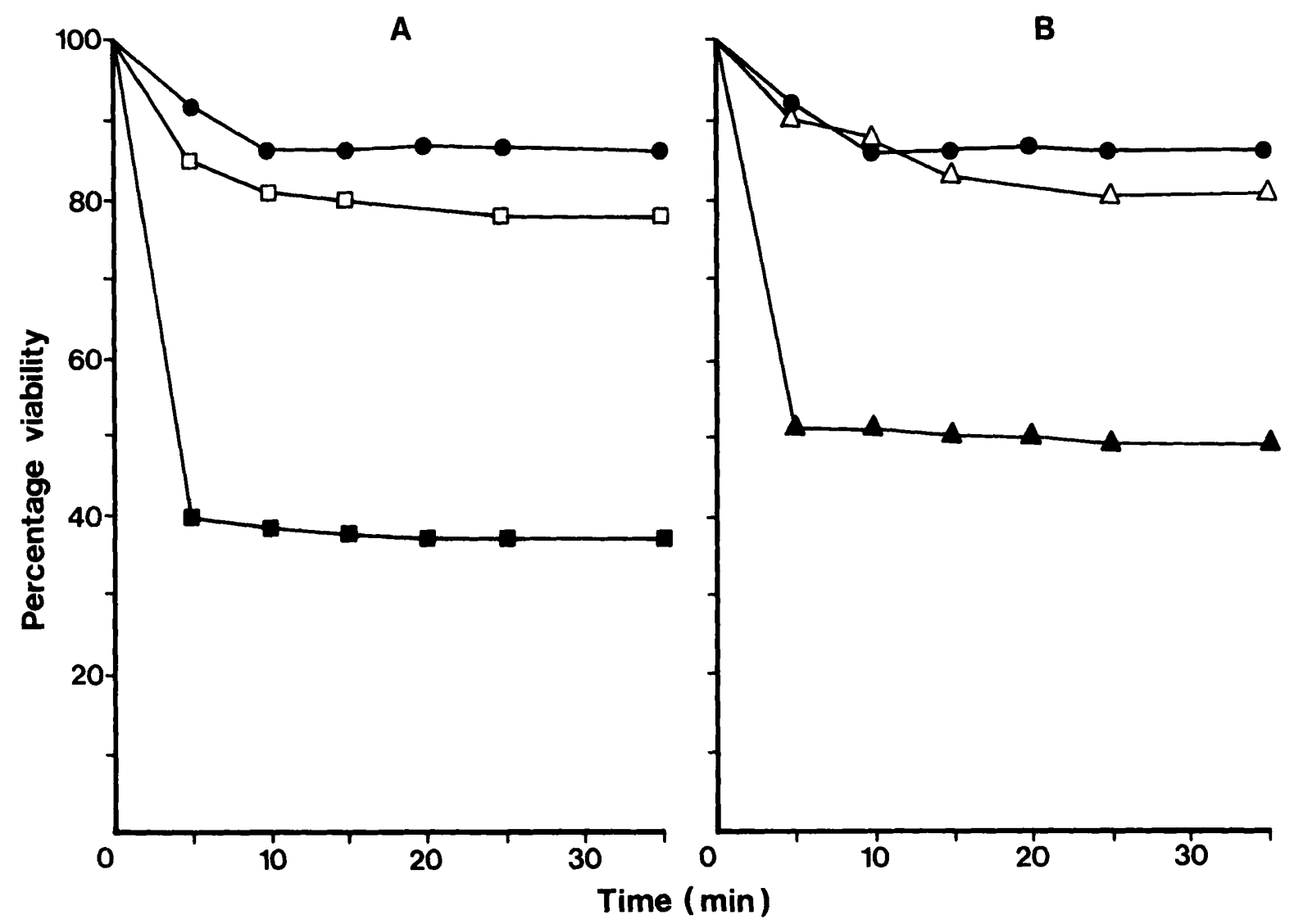

Fig. 2 (A and B). Bactericidal activity of pooled PEC of mice: immunised 3 months before with $S$. enteritidis but not stimulated (- or stimulated with S. enteritidis ( with S. enteritidis ( $\square-\square-\square)$, or S. paratyphi A $(\Delta-\Delta-\Delta)$. 


\section{Discussion}

Diarrhoea-causing salmonellae are ubiquitous and man can contract infection from contaminated water and foods of animal origin. Such infections are often subclinical or cause mild symptoms. If these infections can induce cross-immunity against the salmonellae that cause enteric fever, this would be an important mode of acquiring natural resistance against typhoid. Padmanaban and Mittel (1979) and Nair and Kamat (1982) have shown cross-protection amongst salmonellae across the serogroup limits. In the light of these reports the present study was performed. Extensive crossreactions with a pattern of variance with the Kauffman-White scheme were observed in tests of DH. Because DH does not necessarily imply protective CMI (Youman, 1975), it was essential to show that these observations correlated with cross-protection. As salmonellae are facultative intracellular parasites they can only be eliminated effectively by AM (Collins, 1974). Hence ability of the interaction of $T$ cells with antigen to generate AM can be employed as an index of protective CMI (Kulkarni and Kamat 1985). Our results show that in mice

\section{REFERENCES}

Blanden R V, Mackaness G B, Collins F M 1966 Mechanisms of acquired resistance in mouse typhoid. Journal of Experimental Medicine. 124:585-600.

Collins F M 1974 Vaccines and cell-mediated immunity. Bacteriological Reviews 38:371-402.

Edwards P R, Ewing W H 1972 Identification of Enterobacteriaceae, 3rd edn, Burgess Publishing Co., Minneapolis, p 213.

Freund J E 1967 Modern Elementary Statistics, 3rd edn. Prentice-Hall, Inc, Englewood Cliffs, New Jersey, p 225.

Gray D F, Jennings P A 1955 Allergy in experimental mouse tuberculosis. American Review of Tuberculosis 72: 171-195.

Kulkarni S G, Kamat R S 1985 Cross-reactions in cell mediated immunity of atypical mycobacteria. Journal of Medical Microbiology, 21:35-38. immunised with $S$. paratyphi B, whereas the $\mathrm{DH}$ cross-reacting $S$. poona sonicate generated AM, the non-cross-reacting $S$. typhi sonicate did not. It could be argued that the observed enhancement of bactericidal activity of PEC is due to non-specific activation by lipopolysaccharides and other products in the sonicates (Morrison and Ryan, 1979). This is most unlikely because the sonicates did not enhance the bactericidal activity of PEC of nonimmune mice. These data clearly establish that the observed cross-reactions in the DH response have cross-protective implications.

The objective of this investigation was to see if natural infection with salmonellae that cause diarrhoea could generate protective CMI against salmonellae that cause enteric fever, therefore reverse experiments employing an example of the former type, $S$. enteritidis, as immunogen were also performed. Similar cross-reactions in DH response and in the ability to generate AM were elicited by the sonicate of $S$. paratyphi A. Thus the findings reported so far clearly establish that the target antigens of CMI in enteric fever-causing and other salmonellae show extensive cross-reactions.

Lowry O H, Rosebrough N J, Farr A L, Randall R J 1951 Protein measurement with the folin phenol reagent. Journal of Biological Chemistry 193: 265-275.

Morrison D C, Ryan J L 1979 Bacterial endotoxins and host immune responses. Advances in Immunology 28:293-450.

Nair R, Kamat R S 1982 Effector cell-mediated immune response in mice immunised with Salmonella. Journal of Medical Microbiology, 15:215-221.

Padmanaban V D, Mittal K R 1979 Cross-protection against Salmonella enteritidis infection in mice. I. Immunization trials. Acta Microbiologica Academiae Scientiarum Hungaricae 26:277-281.

Youmans G P 1975 Relation between delayed hypersensitivity and immunity in tuberculosis. American Review of Respiratory Diseases 111: 109-118. 